\title{
A Review on the Effects of Flame Retardant Additives Towards the Environment and Human Health
}

\author{
Bebianna Lim Chean-Yiing ${ }^{1}$, Sara Yasina Yusuf ${ }^{2, *}{ }^{\mathbb{D}}$, Nor Ruwaida Jamian ${ }^{3}$, Rafiziana Md. Kasmani ${ }^{4}$, \\ Ammar Mohd. Rashid ${ }^{5}$, Dewika Naidu ${ }^{6}$, Edza Aria Wikurendra ${ }^{7 \mathbb{D}}$, Abdul Hakim Zakkiy Fasya ${ }^{7(\mathbb{D})}$ \\ 1 Faculty of Civil Engineering Technology, Universiti Malaysia Perlis, Kompleks Pusat Pengajian Jejawi 3, 02600 Arau, \\ Perlis, Malaysia \\ 2 Centre of Excellence, Water Research and Environmental Sustainable Growth (WAREG), Universiti Malaysia Perlis, \\ 02600, Perlis, Malaysia \\ 3 Air Resources Laboratory, Malaysia-Japan International Institute of Technology, 54100 UTM Kuala Lumpur, Malaysia \\ 4 Center of Hydrogen Energy (CHE), Universiti Teknologi Malaysia, 81310 UTM Johor Bahru, Johor, Malaysia \\ 5 AMR Environmental Sdn. Bhd., Taman Sri Pulai Perdana, 81110 Johor Bahru, Malaysia \\ 6 Centre of America Education, Sunway University, Bandar Sunway, 47500 Selangor, Malaysia \\ 7 Department of Public Health, Universitas Nahdlatul Ulama Surabaya, 60237 Surabaya, Indonesia \\ * Correspondence: sarayasina@unimap.edu.my (S.Y.Y.);
}

Received: 29.09.2021; Revised: 10.11.2021; Accepted: 14.11.2021; Published: 5.12.2021

\begin{abstract}
Flame retardant additives (FRAs) are normally the addition of chemicals that function to prevent or slow the spread of fires. These chemicals are used in consumer products and industries and could retain in the environment even after several decades. The toxicity mechanism and risk assessment methods of FRAs are also discussed in this paper. Papers from Scopus, Elsevier, Environmental health perspectives (EHP), Research gate, Semantic scholar, Hindawi, and Pubmed from 2003 to recent years were reviewed to provide some views on the possible risks of FRAs and their pathways into our environment as well as into human body. While FRAs could enter the environment during the manufacturing process and the usage period, consumer items are treated with FRAs, through waste streams, during illegal open burning of solid wastes, from incineration plants from landfill leachate and wastewater treatment plant (WWTP) sludge. FRAs are hazardous to humans and the environment; therefore, toxicology assessment should also be consistently conducted on the latest FRAs to ensure that they would not have adverse effects on humans and the environment.
\end{abstract}

Keywords: environmental pollution; human exposure; health risk assessment; SDG-3; silver nanoparticles; halogens.

(C) 2021 by the authors. This article is an open-access article distributed under the terms and conditions of the Creative Commons Attribution (CC BY) license (https://creativecommons.org/licenses/by/4.0/).

\section{Introduction}

Flame retardant (FRs) is a type of chemical that can be added or layered onto combustible material to prevent or slow the spread of fires. This chemical is widely used in consumers and industrial products [1,2]. However, most of the commercial FRs used back in the day are now removed from the market. The nature of FRs that are highly resilient and can remain in the environment for decades is the primary concern. It has also been identified that those FRs can bio-accumulate or retain in both humans and the environment [2]. During the manufacturing of FRs, the chemicals present in them would leak into water and soil, while the smaller dust particles from the chemicals used to produce FRs would become air-borne particles. The widespread use of FRs in producing a wide range of consumer goods has resulted 
in unavoidable environmental discharges and human exposures [3]. There are three identified exposure routes for humans (inhalation, ingestion, and dermal contact), while there are several ways for the chemicals to enter the environment (wastewater, burning, landfill leachate, chemical production, etc.).

Nowadays, bio-composites are rapidly gaining popularity among various industries due to their cost-friendly and sustainable properties. As more bio-composites are being manufactured, their flame retarding properties should also be considered according to the Malaysian Standards for Fire Safety and Protection [4]. FRs can be added to bio-composites to enhance further the flame retarding properties of the materials; in this case, the FRs are known as FRAs. These FRAs are also chemicals with their unique flame retarding mediums, whereby the halogen mentioned previously is one of the types of FRAs. This study focuses on two types of FRAs, namely halogens and metallic nanometric particles.

Halogens are non-metals and are in group 17 in the periodic table. Halogens are extremely reactive. In large enough quantities, it can be damaging or deadly to biological organisms. The strong electronegativity and effective nuclear charge of halogens contribute to their high reactivity [5]. Research [6] indicated that when exposed to halogens, the lung and other organs will be vulnerable to environmental and occupational hazards. Chlorine causes hypoxemia, dyspnoea, airway blockage, pulmonary edema, pneumonitis, and acute respiratory distress syndrome when inhaled (ARDS). At the same time, inhalation of bromine causes airway hyperresponsiveness, bronchospasm, ARDS, and even mortality, even though it is less reactive and oxidative than chlorine [6]. An example of the dangers of halogen exposure is an incident that occurred in 2005. A local mill in Graniteville of South Carolina, USA, accidentally released $54900 \mathrm{~kg}$ of chlorine, which resulted in the instant death of 8 victims from asphyxiation or acute respiratory failure after exposure on-site [7], while 529 victims survived the ordeal [8]. The surviving victims reported coughs and shortness of breath even after eight to ten months after the incident [9].

On the other hand, metallic nanometric particles or engineered nanomaterials are engineered chemical substances or materials with particle sizes between 1 to $100 \mathrm{~nm}$ and are separated into two categories; organic and inorganic [10]. The smaller size of nanometric particles allows it to cover a larger surface area and enables penetration into hard-to-reach areas. The previous study concluded three main reasons why nanometric particles are hazardous [11]: (1) it can penetrate deep into the lungs, causing significant harm, (2) it could enter the human body through the skin, lungs, or digestive system, generating "free radicals" to harm cells and DNA, and (3) the human body lacks natural immunity to novel compounds; hence nanometric particles would most likely be classified as harmful. Inhalation of carbon nanotubes suppresses the immune system by altering $\mathrm{T}$ cell activity, whereas exposure to nanoparticles causes brain injury in fish and dogs because nanometric particles can pass through the blood-brain barrier and move into the brain [11].

This paper focuses on bromine as the halogenated FRAs (BFRAs) and silver nanoparticles (AgNPs) as the metallic nanometric particle FRAs. The exposure routes to humans and entrance pathways to the environment of bromine and AgNPs additives will be further discussed in this paper. Other than that, the toxicity and health risk assessments conducted by previous studies will also be elaborated in this review, together with the relevant research results. It is important to conduct toxicology and health risk assessments, especially for novel chemicals that are introduced as potential FRAs. This is crucial as flame retardants are widely used in consumer products, buildings, and constructions. This paper will further 
highlight the side effects of chemicals on both humans and the environment, showing the importance of toxicology and health risk assessments.

\section{Pathways and Exposure Routes for FRAs into the Environment and Human Body}

The pathways into the environment and exposure routes into the human body for both BFRAs and AgNPs are similar. The major routes of entry of FRAs into the human body: ingestion, inhalation, dermal contact, and directly into the systemic circulation either by intraperitoneal or intravenous injection [1]. The main function of these FRAs is added to increase the .existing flame retardancy efficiency or provide flame retardant properties to consumer products such as furniture and electronic devices [12]. Thus, leading to the leaching of FRAs as it has been found in household dust, personal cars, interior air, and aquatic ecosystems [13].

\subsection{Landfills.}

Wastes such as kitchen wastes, municipal solid wastes, and yard wastes are dumped and buried in landfills. These landfills are exposed to the environment, and rainwater is free to flow and seep through the soil and buried wastes. The rainwater will mix with the degrading waste and form leachate, while the waste that degrades over time will form sediments. The leachate and sediments formed in the landfill are a complex mixture containing organic and inorganic compounds, influenced by the composition and solubility of the waste constituents [14]. A landfill is a significant source of existing environmental FRAs [15] as unwanted consumer products that contain FRAs are dumped into a landfill. The landfill is a significant food source for various vertebrates and a source of environmental pollution [16,17]. There are two main pathways for FRAs to enter the environment: leaching leachate to groundwater and emission into the air [18]. These two pathways were promoted by the photolytic and biodegradation of high molecular weight.

\subsection{Wastewater treatment plants.}

Wastewater sources may be from industrial, commercial, and domestic use and are released into the environment, such as oceans, lakes, and rivers. Wastewater is made up of 99.9\% water and $0.1 \%$ organic matter. The organic content in wastewater originates from protein, fat, human feces, sugar material, and vegetables from food preparation and soap [19]. Polybrominated diphenyl ethers (PBDE) and novel brominated flame retardants (NBFRs) found in manufacturing, industrial and domestic waste may enter wastewater streams and would often preserve in sludge during the municipal treatment process [20]. These BFRAs and other substances may enter the environment through effluent discharge and biosolid land application [21]. PBDE is still the main concern as it is present in various consumer products and is discharged into the environment through WWTPs [22].

While for silver nanoparticles it is widely applied in consumer clothing articles due to their antibacterial property. When washed, AgNPs would enter the wastewater stream [23-25]. Even though most of the silver nanoparticles would be removed in the WWTPs process, there are still traces of AgNPs that retain in the WWTPs effluent [26,27]. Other than that, the AgNPs removed would retain in the WWTPs sludge, leading to soil contamination when the sludge is applied to soil for nutrient rectification [28,29]. 


\subsection{Soil.}

FRAs may enter the environment through atmospheric emissions from sources such as waste incineration, manufacturing, recycling facilities, and other industrial processes [20]. The chemicals that enter the environment can travel long distances in the air and settle on the soil. Another way for FRAs to contaminate soil is the application of wastewater treatment sludge to the soil for nutrient rectification as high concentrations of contamination are retained in sludge. In addition, leachate from landfills that do not have a bottom liner or a punctured bottom liner could seep through soil and travel with the underground water to contaminate larger soil areas.

\subsection{Indoor dust.}

Dust is made up of complex heterogeneous mixtures of organic compound and particlebound matters. Indoor dust consists of materials that can be found within our homes, such as animal hair, textile fibers, human skin cells, and paper fibers. While outdoor dust is a combination of outdoor sources materials such as soil particles, vehicle combustion particles, pollen, or insect follicle parts [30]. FRAs combined with dust from outside our home could enter the house when the door or windows are opened or dust that adhered to our clothing when we were outside. The FRAs that are mixed with environmental dust are released during the manufacturing, washing, or disposal process of a product containing FRAs [31]. FRAs have often been discovered in indoor dust at concentrations surpassing $1 \mu \mathrm{g} / \mathrm{g}$ [32]. Indoor dust is one of the major sources of human exposure to environmental contaminants and leads to a higher chance of toddlers' exposure to FRAs.

\subsection{Breastmilk and blood or serum.}

As FRAs are lipophilic in nature, food high in lipid content tends to have a higher contamination level. Therefore, the highest concentration levels can be found in aquatic foods, then meat, animal and vegetable fats, oils, dairy products, and finally eggs [33]. Mothers that ingest food contaminated with FRAs would be contaminated, which leads to bioaccumulation of FRAs in their bodies. Human breast milk and blood or serum is one of the exposure pathways of FRAs to infants. Infants obtain nutrients from their mothers' placenta (blood and serum transfer), which causes a contaminant transfer. After delivery, infants will feed on their mothers' breast milk, another pathway for contamination transfer. Therefore, breast milk and blood or serum are used as markers to assess human exposure and provide details on contaminant transfer from mother to infant [14].

\section{Toxicity of FRAs to the Environment and Humans}

FRAs are known to have the ability to accumulate in humans, animals, and the environment. Other than that, some researchers found that the FRAs in a mother's body could be transferred to a child either through placenta or breastmilk. This signifies that each child has been contaminated since they are still a fetus or a baby. It is difficult to study the toxicity of FRAs as a group because their physicochemical features are so diverse [3].

\subsection{Ecotoxicity.}

BFRAs such as PBDE were detected in birds' eggs and were linked as a culprit to the decline in breeding success and further decreasing their population [34]. Failed eggs were 
collected as it is a less intrusive analysis method. Previous study conducted stable isotope analysis, which indicated that the glaucous-winged gulls from the Salish Sea had become more dependent on terrestrial invertebrates and human refuses instead of their natural marine food [35]. This caused the decrease in clutch size and egg volume of that species starting as early as the 20th Century [36]. The authors from ref [37] identified that exposure to PBDE disrupts the thyroid system of common starlings. The oxidative metabolism of PBDE in the liver microsomes of juvenile common starlings is lowered, according to [38], implying that certain PBDE is likely to accumulate in individuals over time. The ring-billed gulls that breed in Quebec, Canada, were found to have demineralized bones due to PBDE exposure [39] and liver type-1 deiodinase mRNA conversely associated with hepatic $\sum$ octa-BDE [40].

The widespread use of AgNPs could lead to severe consequences to microorganisms living in natural systems [25]. AgNPs are also listed under the priority engineered nanomaterials needed to undergo environmental risk assessment (ERA) [41]. It was found that silver ions $\left(\mathrm{Ag}^{+}\right)$are potentially toxic to bacteria that are crucial towards nitrogen fixation in soil. Whereby the bactericidal activity of $\mathrm{Ag}^{+}$prevents microbial growth in soil $[42,43] . \mathrm{Ag}^{+}$ interrupts environmental denitrification, leading to eutrophication in water bodies, a major drinking water pollutant [44]. Acute silver toxicity appeared to be induced mainly by silver ions interaction with the fish gills, disrupting basolateral sodium and potassium ion-ATPase activity, resulting in suppression of active sodium $\left(\mathrm{Na}^{+}\right)$and chloride $\left(\mathrm{Cl}^{-}\right)$ion intake and thus osmoregulation by the fish [45]. In order to analyze the hazards associated with the widespread usage of AgNPs, it is necessary to assess the effects of AgNPs on diverse cells as well as individual organisms, as well as the probability of their translocation in trophic chains via deposition in the plant, human, and animal tissues [46]. Compared to nanoparticles coated with peptides, AgNPs were shown to have a greater lethality [47]. The toxic effects of $\mathrm{Ag}^{+}$were higher than that of AgNPs, and therefore more research is needed to determine how nanoparticles (NPs) behave under environmental conditions such as the presence of cations and anions, $\mathrm{pH}$, and the percentage of dissolved organic carbon. [48]. Another study by [49] found that the decrease in root length and germination rate are common side effects of the phytotoxic activity of AgNPs. It is noted that reactive oxygen species (ROS) production and bacterial cell porosity changes are the common silver toxicity mechanisms [50]. However, the phototransformation, dissolution, or aggregation of AgNPs to soil particles may decrease AgNPs toxicity towards microorganisms [51]. In general, BFRAs and AgNPs' ecotoxicities are summarized in Table 1.

Table 1. Summary of BFRAs and AgNPs ecotoxicity.

\begin{tabular}{|c|c|c|}
\hline Type of FRAs & Effects & Reference \\
\hline \multirow{5}{*}{$\begin{array}{c}\text { BFRAs } \\
\left(\text { PBDE, } \sum \text { octa-BDE) }\right.\end{array}$} & Decreases clutch size and egg volume of glaucous-winged gulls' & [36] \\
\hline & Disrupts common starlings' thyroid system & [37] \\
\hline & $\begin{array}{l}\begin{array}{l}\text { Diminishes juvenile common starlings' liver oxidative } \\
\text { metabolism }\end{array} \\
\end{array}$ & [38] \\
\hline & Demineralization of ring-billed gulls' bones & [39] \\
\hline & Causes liver type- deiodinase mRNA in ring-billed gulls & [40] \\
\hline \multirow{4}{*}{ AgNPs } & Prevents microbial growth in soil & [42], [43] \\
\hline & $\begin{array}{l}\text { Disrupts environmental denitrification leading to uncontrolled } \\
\text { eutrophication }\end{array}$ & [44] \\
\hline & $\begin{array}{l}\text { Restrain active } \mathrm{Na}^{+} \text {and } \mathrm{Cl}^{-} \text {ion intake, interrupting } \\
\text { osmoregulation in fish }\end{array}$ & [45] \\
\hline & Decreases root length and germination rate of plants & {$[50]$} \\
\hline
\end{tabular}




\subsection{Toxicity to the human body.}

BFRAs are lipophilic, able to retain and accumulate in the lipids of animals and fish. The harmful effects of BFRAs are due to their persistency and ability to bio-magnify and bioaccumulate in humans [52]. The pediatric serum has higher concentrations of BFRAs than adults' serum [53-55]. They identified that breastfeeding and dust ingestion from children's mouthing behavior is the main contributor to the higher levels of BFRAs. The concentration of BFRAs in a fetus is remarkably similar to the concentration of BFRAs in their mothers [56]. As PBDE, a type of BFRAs, has a similar chemical structure with thyroid hormones (triiodothyronine, T3, and thyroxin, T4), PBDE can imitate and interrupt homeostatic conditions within the human body [57]. A study by [58] suggested that PBDE can cause autism or affect brain development. Children with higher PBDE concentrations scored lower in neurodevelopment tests than other children with lower concentrations of PBDE [59]. In human populations, PBDE and organophosphorus FRAs (OPFRAs) have also been linked to neurological and reproductive problems [60]. FRAs exposure appears to affect neurodevelopment, morphogenesis, muscle development, immune development, metabolism, and the development of numerous organs like the liver and heart. According to the data presented by [61-63], that chlorinated FRAs, BDE-47, and aryl FRAs interrupt the neurodevelopmental genes. Tetrabromobisphenol A (TBBPA), a type of BFRAs, were found to possibly induce increased expression of several genes involved in ROS production and osteoclast differentiation and promote the lysosomal exocytosis in cancer cells $[64,65]$. According to [59], TBBPA has been linked to thyroid abnormalities, neurobehavioral and developmental issues, reproductive health, immunological, oncological, and cardiovascular diseases. Human umbilical vein endothelial cells (HUVESs) were also found to be sensitive to PBDEs, while BDE-209 triggers HUVECs apoptosis and autophagy [66]. HUVECs' physiology and vascular function could be upset by NBFRs and their metabolites [67].

In the case of AgNPs, it is known to have the "Trojan-horse effect". This effect can be explained as the mechanism of nanotoxicity where AgNPs can penetrate through biological barriers and accumulate in cells. As time passes, it would release $\mathrm{Ag}^{+}$in high local concentrations when oxidizing agents are present. The silver element is harmless but not the $\mathrm{Ag}^{+}$, as it is the main contributor to AgNPs toxicity [68].

Table 2. Summary of BFRAs and AgNPs toxicity to the human body.

Type of FRAs

\begin{tabular}{c|l|c}
\multicolumn{1}{c|}{ Type of FRAs } & \multicolumn{1}{c|}{ Effects } & Reference \\
\hline \multirow{5}{*}{$\begin{array}{c}\text { BFRAs } \\
\text { (PBDE, BDE-47, TBBPA) }\end{array}$} & $\begin{array}{l}\text { Lipophilic nature causes it to be able to bio-magnify and bio- } \\
\text { accumulate }\end{array}$ & {$[52]$} \\
\cline { 2 - 3 } & Imitates thyroid hormones, interrupting homeostatic conditions & {$[57]$} \\
\cline { 2 - 3 } & Causes autism or affect brain development & {$[58]$} \\
\cline { 2 - 3 } & Linked to neurobiological and reproductive problems & {$[60]$} \\
\cline { 2 - 3 } & Disrupts neurodevelopmental genes & {$[61-63]$} \\
\cline { 2 - 3 } & $\begin{array}{l}\text { Increases the expression of genes involved in ROS production } \\
\text { and promote lysosomal exocytosis in cancer cells }\end{array}$ & {$[64,65]$} \\
\cline { 2 - 3 } & Triggers HUVECs apoptosis and autophagy & {$[66]$} \\
\hline \multirow{2}{*}{ AgNPs } & Lead to blueish tinting of skin (argyria) and eyes (argyrosis) & {$[69]$} \\
\cline { 2 - 3 } & $\begin{array}{l}\text { Able to pass blood-testes barrier and deposit in testes, harming } \\
\text { sperm cells }\end{array}$ & {$[71]$} \\
\cline { 2 - 3 } & $\begin{array}{l}\text { Causes ROS production leading to protein denaturation, } \\
\text { membrane malfunction, apoptosis or genetic material damage }\end{array}$ \\
\cline { 2 - 3 } & $\begin{array}{l}\text { Excessive ROS production, damaging biological components via } \\
\text { oxidation of DNA, proteins and lipids }\end{array}$ & {$[72]$} \\
\hline
\end{tabular}

An estimation made by [1] was that humans ingest approximately 20 to $28 \mu \mathrm{g}$ of silver daily. When exposed for extended periods to colloidal silver or silver salt deposits, it would 
lead to skin diseases such as argyria (skin) or argyrosis (eyes), which appears to be a bluish tint [25]. As AgNPs can pass through the blood-testes barrier, they could deposit in the testes and harm the sperm cells [69]. NPs can be administered in various ways, resulting in them passing biological barriers, being transported through the bloodstream, and then being distributed and deposited in various tissues and organs [70]. As a result, the kinetics of these processes should be carefully considered. Moreover, NPs or the $\mathrm{Ag}^{+}$released from AgNPs influence cells via ROS production, resulting in protein denaturation, membrane malfunction, apoptosis, or genetic material damage [71-79]. Excess ROS production could damage biological components via the oxidization of DNA, proteins, and lipids [80-87]. In general, BFRAs and AgNPs toxicities to the human body are summarized in Table 2.

\section{Conclusions}

FRAs are harmful to both humans and the environment. It can retain and bioaccumulate and bio-magnify in humans, animals, and the environment. FRAs enter the human body via ingestion, inhalation, dermal contact, and directly into the systemic circulation through intraperitoneal or intravenous injection. The environment is more susceptible to FRAs pollution as FRAs could enter the environment during the manufacturing process, during the usage period consumer items treated with FRAs, through waste streams, during illegal open burning of solid wastes, from incineration plants from landfill leachate and WWTP sludge. It can be concluded that all FRAs have similar entry routes into the environment and the human body. To prevent substantial amounts of these chemicals from entering the environment and our bodies, manufacturers should use FRAs in moderation. Waste streams should be properly treated before release, and sludge is tested from traces of FRAs before being used as nutrient source alternatives. Toxicology assessment should also be consistently conducted on the latest FRAs and FRs to ensure that it would not adversely affect humans and the environment. This is to ensure that future generations can live in a safer and cleaner environment. It is recommended in future studies to conduct toxicology assessments using in silico method to create a database to ease future researchers in identifying the side effects of the chemicals before mast production.

\section{Funding}

This research was funded by Collaborative Research Grant UTM-UniMAP under a grant number of 9023-00018 from Universiti Teknologi Malaysia and Universiti Malaysia Perlis.

\section{Acknowledgments}

The authors wish to convey appreciation to the technical and administrative staff at the Faculty of Civil Technology, UniMAP.

\section{Conflicts of Interest}

The authors declare no conflict of interest.

\section{References}

1. Matteis, V.D. Exposure to inorganic nanoparticles: routes of entry, immune response, biodistribution and in vitro/in vivo toxicity evaluation. Toxics 2017, 5, https://doi.org/10.3390/TOXICS5040029. 
2. National Institute of Environmental Health Sciences. Available online: https://www.niehs.nih.gov/health/topics/agents/flame_retardants/index.cfm (accessed on 12 April 2021).

3. Dasgupta, S.; Dunham, C.L.; Truong, L.; Simonich, M.T. Sullivan; C.M.; Tanguay, R.L. Phenotypically anchored mRNA and miRNA expression profiling in zebrafish reveals flame retardant chemical toxicity networks. Front in Cell and Dev Bio 2021, 654, https://doi.org/10.3389/FCELL.2021.663032.

4. Malaysian Fire Protection Association. Malaysian Standards. Available online: https://mfpa.com.my/malaysian-standards/ (accessed on 01 July 2021).

5. Boundless Chemistry. Halogens. Lumen Candela. Available online: https://courses.lumenlearning.com/boundless-chemistry/chapter/halogens/ (accessed on 24 July 2021)

6. Zhou, T.; Song, W.F.; Shang, Y.; Yao, S.L.; Matalon, S. Halogen inhalation-induced lung injury and acute respiratory distress syndrome. Chi Med J 2018, 131, https://doi.org/10.4103/0366-6999.231515.

7. Balte, P.P.; Clark, K.A.; Mohr, L.C.; Karmaus, W.J.; van-Sickle, D.; Svendsen, E.R. The immediate pulmonary disease pattern following exposure to high concentrations of chlorine gas. Pul Med 2013, 2013, 1-7, https://doi.org/10.1155/2013/325869.

8. Van Sickle, D.; Wenck, M.A.; Belflower, A.; Drociuk, D.; Ferdinands, J.; Holguin, F.; Svendsen, E.; Bretous, L.; Jankelevich, S.; Gibson, J.J.; Garbe, P.; Moolenaar, R.L. Acute health effects after exposure to chlorine gas released after a train derailment. The Ame $J$ of Emer Med 2009, 27, 1-7, https://doi.org/10.1016/J.AJEM.2007.12.006.

9. Clark, K.A.; Chanda, D.; Balte, P.; Karmaus, W.J.; Cai, B.; Vena, J.; Lawson, A.B.; Mohr, L.C.; Gibson, J.J.; Svendsen, E.R. Respiratory symptoms and lung function 8-10 months after community exposure to chlorine gas: a public health intervention and cross-sectional analysis. BMC Pub Health 2013, 13, https://doi.org/10.1186/1471-2458-13-945.

10. Madkour, L.H. Nanoelectronic Materials. 1st ed.; Springer International Publishing: Cham, Switzerland, 2019; https://doi.org/10.1007/978-3-030-21621-4.

11. Nanotechnology - a new hazard. Occupational Health and Safety Reps. Available online: https://www.ohsrep.org.au/nanotechnology_-_a_new_hazard (accessed on 25 July 2021).

12. Prabhakar, M.N.; Shah, A.U.R.; Song, J.I. A Review on the Flammability and Flame Retardant Properties of Natural Fibers and Polymer Matrix Based Composites. Compos Res 2015, 28, 29-39, https://doi.org/10.7234/composres.2015.28.2.029.

13. Reddam, A.; Tait, G.; Herkert, N.; Hammel, S.C.; Stapleton, H.M.; Volz, D.C. Longer commutes are associated with increased human exposure to tris(1,3-dichloro-2-propyl) phosphate. Env Int 2020, 136, https://doi.org/10.1016/J.ENVINT.2020.105499.

14. Brits, M.; de-Vos, J.; Weiss, J.M.; Rohwer, E.R.; de-Boer, J. Critical review of the analysis of brominated flame retardants and their environmental levels in Africa. Chemosphere 2016, 164, 174-189, https://doi.org/10.1016/j.chemosphere.2016.08.097.

15. Stubbings, W.A.; Harrad, S. Extent and mechanisms of brominated flame retardant emissions from waste soft furnishings and fabrics: A critical review. Env Int 2014, 71, 164-175, https://doi.org/10.1016/J.ENVINT.2014.06.007.

16. Plaza, P.I.; Lambertucci, S.A. How are garbage dumps impacting vertebrate demography, heath, and conservation? J G Ec Co 2017, 12, 9-20, https://doi.org/10.1016/j.gecco.2017.08.002.

17. Oro, D.; Genovart, M.; Tavecchia, G.; Fowler, M.S.; Martínez-Abraín, A. Ecological and evolutionary implications of food subsidies from humans. Eco Let 2013, 16, 1501-1514, https://doi.org/10.1111/ele.12187.

18. Stubbings, W.A.; Harrad, S. Extent and mechanisms of brominated flame retardant emissions from waste soft furnishings and fabrics: A critical review. Env Int 2014, 71, 164-175, https://doi.org/10.1016/j.envint.2014.06.007.

19. Tuser, C. What is Wastewater? Water \& Wastes Digest 2020.

20. McGrath, T.J.; Ball, A.S.; Clarke, B.O. Critical review of soil contamination by polybrominated diphenyl ethers (PBDEs) and novel brominated flame retardants (NBFRs); concentrations, sources and congener profiles. Env Pollu 2017, 230, 741-757, https://doi.org/10.1016/j.envpol.2017.07.009.

21. Shen, J.; Smyth, S.A.; Droste, R.; Delâge, D. Variability of release rate of flame retardants in wastewater treatment plants. Env Sci and Pollu Res 2018, 25,34740-34752, https://doi.org/10.1007/s11356-018-3403-2.

22. Andrade, N.A.; Lozano, N.; McConnell, L.L.; Torrents, A.; Rice, C.P.; Ramirez, M. Long-term trends of PBDEs, triclosan, and triclocarban in biosolids from a wastewater treatment plant in the Mid-Atlantic region of the US. J of Haz Mat 2015, 282, 68-74, https://doi.org/10.1016/j.jhazmat.2014.09.028.

23. Ghasemzadeh, G.; Momenpour, M.; Omidi, F.; Hosseini, M.R.; Ahani, M.; Barzegari, A. Applications of nanomaterials in water treatment and environmental remediation. Front of Env Sci \& Eng 2014, 8, 471-482, https://doi.org/10.1007/S11783-014-0654-0.

24. Islam, M.A.; Jacob, M.V.; Antunes, E. A Critical review on silver nanoparticles: From synthesis and applications to its mitigation through low-cost adsorption by biochar. $J$ of Env Man 2021, 281, https://doi.org/10.1016/J.JENVMAN.2020.111918.

25. Panyala, N.R. Peña-Méndez, E.M.; Havel, J. Silver or silver nanoparticles: A hazardous threat to the environment and human health?. J of App Biomed 2008, 6, 117-129, https://doi.org/10.32725/JAB.2008.015. 
26. Kaegi, R.; Voegelin, A.; Ort, C.; Sinnet, B.; Thalmann, B.; Krismer, J.; Hagendorfer, H.; Elumelu, M.; Mueller, E. Fate and transformation of silver nanoparticles in urban wastewater systems. Water Research 2013, 47, 3866-3877, https://doi.org/10.1016/J.WATRES.2012.11.060.

27. Blaser, S.A.; Scheringer, M.; MacLeod, M.; Hungerbühler, K. Estimation of cumulative aquatic exposure and risk due to silver: Contribution of nano-functionalized plastics and textiles. Sci of The Tot Env 2008, 390, 396-409, https://doi.org/10.1016/J.SCITOTENV.2007.10.010.

28. Moore, J.D.; Stegemeier, J.P.; Bibby, K.; Marinakos, S.M.; Lowry, G.V.; Gregory, K.B. Impacts of Pristine and Transformed $\mathrm{Ag}$ and $\mathrm{Cu}$ engineered nanomaterials on surficial sediment microbial communities appear short-lived. Env Sci and Tech 2016, 50, 2641-2651, https://doi.org/10.1021/ACS.EST.5B05054.

29. Doolette, C.L; McLaughlin, M.J. Kirby, J.K.; Navarro, D.A. Bioavailability of silver and silver sulfide nanoparticles to lettuce (Lactuca sativa): Effect of agricultural amendments on plant uptake. J of Haz Mat 2015, 300, 788-795, https://doi.org/10.1016/J.JHAZMAT.2015.08.012.

30. Hales, D. What is Dust Made Of? You might be surprised! Modern Castle 2020. Available online: https://moderncastle.com/blog/what-is-dust-made-of/ (accessed on 01 June 2021).

31. Qiao, H.; Liu, W.; Gu, H.; Wang, D.; Wang, Y. The transport and deposition of nanoparticles in respiratory system by inhalation. J of Nanomat 2015, 2015, https://doi.org/10.1155/2015/394507.

32. Chen, Y.; Cao, Z.; Covaci, A.; Li, C.; Cui, X. Novel and legacy flame retardants in paired human fingernails and indoor dust samples. Env Int 2019, 133, https://doi.org/10.1016/J.ENVINT.2019.105227.

33. Fromme, H.; Becher, G.; Hilger, B.; Völkel, W. Brominated flame retardants - Exposure and risk assessment for the general population. Int $J$ of Hyg and Env Health 2016, 219, 1-23, https://doi.org/10.1016/j.ijheh.2015.08.004.

34. Daso, A.P.; Okonkwo, J.O.; Jansen, R.; Forbes, P.B.C.; Kotzé, A.; Rohwer, E.R. Polybrominated diphenyl ethers (PBDEs) in eggshells of the Southern Ground-Hornbill (Bucorvus leadbeateri) and Wattled Crane (Bugeranus carunculatus) in South Africa. Chemosphere 2015, 118, 284-292, https://doi.org/10.1016/j.chemosphere.2014.09.063.

35. Hobson, K.A.; Blight, L.K.; Arcese, P. Human-induced long-term shifts in gull diet from marine to terrestrial sources in North America's coastal pacific: more evidence from more isotopes $(\delta 2 \mathrm{H}, \delta 34 \mathrm{~S})$. Env Sci Tech 2015, 49, 10834-10840, https://doi.org/10.1021/ACS.EST.5B02053.

36. Blight, L.K.; Hobson, K.A.; Kyser, T.K.; Arcese, P. Changing gull diet in a changing world: A 150-year stable isotope $(\delta 13 \mathrm{C}, \delta 15 \mathrm{~N})$ record from feathers collected in the Pacific Northwest of North America. Glob Cha Bio 2015, 21, 1497-1507, https://doi.org/10.1111/gcb.12796.

37. Eng, M.L.; Elliott, J.E.; Williams, T.D. An assessment of the developmental toxicity of BDE-99 in the European starling using an integrated laboratory and field approach. Ecotox 2014, 23, 1505-1516, https://doi.org/10.1007/s10646-014-1292-9.

38. Erratico, C.; Currier, H.; Szeitz, A.; Bandiera, S.; Covaci, A.; Elliott, J. Levels of PBDEs in plasma of juvenile starlings (Sturnus vulgaris) from British Columbia, Canada and assessment of PBDE metabolism by avian liver microsomes. Sci of the Total Env 2015, 518-519, 31-37, https://doi.org/10.1016/j.scitotenv.2014.12.102.

39. Plourde, S.P.; Moreau, R.; Letcher, R.J.;Verreault, J. Is the bone tissue of ring-billed gulls breeding in a pollution hotspot in the St. Lawrence River, Canada, impacted by halogenated flame retardant exposure?. Chemosphere 2013, 93, 2333-2340, https://doi.org/10.1016/j.chemosphere.2013.08.030.

40. François, A.; Técher, R.; Houde, M.; Spear, P.; Verreault, J. Relationships between polybrominated diphenyl ethers and transcription and activity of type 1 deiodinase in a gull highly exposed to flame retardants. Env Tox and Chem 2016, 35, 2215-2222, https://doi.org/10.1002/etc.3372.

41. Karim, M.E. Functional nanomaterials: selected legal and regulatory issues. In: Handbook of Functionalized Nanomaterials for Industrial Applications. Hussain, C.M. Eds; Elsevier: Amsterdam, Netherlands, 2020; pp. 983-994, https://doi.org/10.1016/B978-0-12-816787-8.00030-2.

42. Murata, T.; Kanao-Koshikawa, M.; Takamatsu, T. Effects Of Pb, Cu, Sb, In and Ag contamination on the proliferation of soil bacterial colonies, soil dehydrogenase activity, and phospholipid fatty acid profiles of soil microbial communities. Wat, Air, and Soil Pol 2005, 164, 103-118, https://doi.org/10.1007/S11270-0052254-X.

43. Throbäck, I.N.; Johansson, M.; Rosenquist, M.; Pell, M.; Hansson, M.; Hallin, S. Silver (Ag+) reduces denitrification and induces enrichment of novel nirK genotypes in soil. FEMS Microbio Let 2007, 270, 189194, https://doi.org/10.1111/J.1574-6968.2007.00632.X.

44. Senjen, R. Nanosilver: A threat to soil, water and human health?; Friends of the Earth Australia: Australia, 2007. Available online: https://foe.org/news/2008-10-nanosilver-a-threat-to-soil-water-and-human-health/ (Accessed on 08 June 2021)

45. Bianchini, A.; Playle, R.C.; Wood, C.M.; Walsh, P.J. Mechanism of acute silver toxicity in marine invertebrates. Aqua Tox 2005, 72, 67-82, https://doi.org/10.1016/J.AQUATOX.2004.11.012.

46. Courtois, P.; Rorat, A.; Lemiere, S.; Guyoneaud, R.; Attard, E.; Levard, C.; et al. Ecotoxicology of silver nanoparticles and their derivatives introduced in soil with or without sewage sludge: A review of effects on microorganisms, plants and animals. Env Pol 2019, 253, 578-598, https://doi.org/10.1016/J.ENVPOL.2019.07.053. 
47. Falanga, A.; Siciliano, A.; Vitiello, M.; Franci, G.; Genio, V.; del-Galdiero, S.; Guida, M.; Carraturo, F.; Fahmi, A.; Galdiero, E. Ecotoxicity evaluation of pristine and indolicidin-coated silver nanoparticles in aquatic and terrestrial ecosystem. Int $J$ of Nanomed 2020, 15, 8097-8108, https://doi.org/10.2147/IJN.S260396.

48. Khoshnamvand, M.; Hao, Z.; Fadare, O.O.; Hanachi, P.; Chen, Y.; Liu, J. Toxicity of biosynthesized silver nanoparticles to aquatic organisms of different trophic levels. Chemosphere 2020, 258, https://doi.org/10.1016/J.CHEMOSPHERE.2020.127346.

49. Yan, A.; Chen, Z. Impacts of silver nanoparticles on plants: A focus on the phytotoxicity and underlying mechanism. International J of Mole Sci 2019, 20, https://doi.org/10.3390/IJMS20051003.

50. Sullivan, T.S.; Gadd, G.M. Metal bioavailability and the soil microbiome. Adv in Agro 2019, 155, 79-120, https://doi.org/10.1016/BS.AGRON.2019.01.004.

51. Liu, J.; Williams, P.C. Goodson, B.M.; Geisler-Lee, J.; Fakharifar, M.; Gemeinhardt, M.E. TiO2 nanoparticles in irrigation water mitigate impacts of aged $\mathrm{Ag}$ nanoparticles on soil microorganisms, Arabidopsis thaliana plants, and Eisenia fetida earthworms. Env Res 2019, 172, 202-215, https://doi.org/10.1016/J.ENVRES.2019.02.010.

52. Eljarrat, E.; de-La-Cal, A.; Raldua, D.; Duran, C.; Barcelo, D. Occurrence and Bioavailability of Polybrominated Diphenyl Ethers and Hexabromocyclododecane in Sediment and Fish from the Cinca River, a Tributary of the Ebro River (Spain). Env Sci and Tech 2004, 38, 2603-2608, https://doi.org/10.1021/ES0301424.

53. Sjödin, A.; Wong, L.-Y.; Jones, R.S.; Park, A.; Zhang, Y.; Hodge, C.; DiPietro, E.; McClure, C.; Turner, W.; Needham, L.L.; Patterson, D.G. Serum Concentrations of Polybrominated Diphenyl Ethers (PBDEs) and Polybrominated Biphenyl (PBB) in the United States Population: 2003-2004. Environmental Science \& Technology 2008, 42, 1377-1384, https://doi.org/10.1021/ES702451P.

54. Toms, L.M.L.; Sjödin, A.; Harden, F.; Hobson, P.; Jones, R.; Edenfield, E.; Mueller, J.F. Serum Polybrominated Diphenyl Ether (PBDE) levels are higher in children (2-5 years of age) than in infants and adults. Env Health Persp 2009, 117, 1461-1465, https://doi.org/10.1289/EHP.0900596.

55. Fischer, D.; Hooper, K.; Athanasiadou, M.; Athanassiadis, I.; Bergman, Å. Children show highest levels of polybrominated diphenyl ethers in a California family of four: A case study. Env Health Persp 2006, 114, 1581-1584, https://doi.org/10.1289/EHP.8554.

56. Mazdai, A.; Dodder, N.G.; Abernathy, M.P.; Hites, R.A.; Bigsby, R.M. Polybrominated diphenyl ethers in maternal and fetal blood samples. Child Health Art 2003, 111, https://doi.org/10.1289/ehp.6146.

57. Wikoff D.S.; Birnbaum L. Brominated Flame Retardants. In: The Handbook of Environmental Chemistry. Eljarrat, E.; Barceló, D. Eds; Springer: Heidelberg, Berlin, Volume 16, 2011; pp. 19-53.

58. Messer, A. Mini-review: Polybrominated diphenyl ether (PBDE) flame retardants as potential autism risk factors. Phys \& Behav 2010, 100, 245-249, https://doi.org/10.1016/J.PHYSBEH.2010.01.011.

59. Herbstman Julie, B.; Sjödin, A.; Kurzon, M.; Lederman Sally, A.; Jones Richard, S.; Rauh, V.; Needham Larry, L.; Tang, D.; Niedzwiecki, M.; Wang Richard, Y.; Perera, F. Prenatal exposure to PBDEs and neurodevelopment. Environmental Health Perspectives $2010, \quad 118, \quad 712-719$, https://doi.org/10.1289/EHP.0901340.

60. Doherty, B.T.; Hoffman, K.; Keil, A.P.; Engel, S.M.; Stapleton, H.M.; Goldman, B.D.; Olshan, A.F.; Daniels, J.L. Prenatal exposure to organophosphate esters and cognitive development in young children in the pregnancy, infection, and nutrition study. Env Res 2019, 169, 33-40, https://doi.org/10.1016/J.ENVRES.2018.10.033.

61. Du, J.; Li, H.; Xu, S.; Zhou, Q.; Jin, M.; Tang, J. A review of organophosphorus flame retardants (OPFRs): occurrence, bioaccumulation, toxicity, and organism exposure. Env Sci and Pol Res 2019, 26, 22126-22136, https://doi.org/10.1007/S11356-019-05669-Y.

62. Chen, H.; Seifikar, H.; Larocque, N.; Kim, Y.; Khatib, I.; Fernandez, C.J.; Abello, N.; Robinson, J.F. Using a Multi-Stage hESC Model to Characterize BDE-47 Toxicity During Neurogenesis. Toxicological Sciences 2019, 171, 221-234, https://doi.org/10.1093/TOXSCI/KFZ136.

63. Li, R.; Wang, H.; Mi, C.; Feng, C.; Zhang, L.; Yang, L.; Zhou, B. The adverse effect of TCIPP and TCEP on neurodevelopment of zebrafish embryos/larvae. Chemosphere 2019, 220, 811-817, https://doi.org/10.1016/J.CHEMOSPHERE.2018.12.198.

64. Park, S.Y.; Choi, E.M.; Suh, K.S.; Kim, H.-S.; Chin, S.O.; Rhee, S.Y.; Kim, D.-Y.; Oh, S.; Chon, S. Tetrabromobisphenol A promotes the osteoclastogenesis of RAW264. 7 cells induced by receptor activator of NF-kappa B ligand in vitro. Journal of Korean medical science 2019, 34, https://doi.org/10.3346/JKMS.2019.34.E267.

65. Lyu, L.; Jin, X.; Li, Z.; Liu, S.; Li, Y.; Su, R.; Su, H. TBBPA regulates calcium-mediated lysosomal exocytosis and thereby promotes invasion and migration in hepatocellular carcinoma. Ecotoxicology and Environmental Safety 2020, 192, https://doi.org/10.1016/J.ECOENV.2020.110255.

66. Hou, Y.; Fu, J.; Sun, S.; Jin, Y.; Wang, X.; Zhang, L. BDE-209 induces autophagy and apoptosis via IRE1 $\alpha /$ Akt/mTOR signaling pathway in human umbilical vein endothelial cells. Env Pol 2019, 253, 429438, https://doi.org/10.1016/J.ENVPOL.2019.07.030. 
67. Chen, Y.; Guo, M.; Liu, R.; Ma, L.Q.; Cui, X. Effects of novel brominated flame retardants and metabolites on cytotoxicity in human umbilical vein endothelial cells. Chemosphere 2020, 253, https://doi.org/10.1016/J.CHEMOSPHERE.2020.126653.

68. Park, E.J.; Yi, J.; Kim, Y.; Choi, K.; Park, K. Silver nanoparticles induce cytotoxicity by a Trojan-horse type mechanism. Tox in Vit 2010, 24, 872-878, https://doi.org/10.1016/J.TIV.2009.12.001.

69. McAuliffe, M.E.; Perry, M.J. Are nanoparticles potential male reproductive toxicants? A literature review. Nanotox 2009, 1, 204-210, https://doi.org/10.1080/17435390701675914.

70. Xu, L.; Wang, Y.Y.; Huang, J.; Chen, C.Y.; Wang, Z.X.; Xie, H. Silver nanoparticles: Synthesis, medical applications and biosafety. Theranos 2020, 10, https://doi.org/10.7150/THNO.45413.

71. Liao, C.; Li, Y.; Tjong, S.C. Bactericidal and cytotoxic properties of silver nanoparticles. Int J of Mole Sci 2019, 20, https://doi.org/10.3390/IJMS20020449.

72. Istiqola, A.; Syafiuddin, A. A review of silver nanoparticles in food packaging technologies: Regulation, methods, properties, migration, and future challenges. J. Chin. Chem. Soc. 2020, 67, 1942-1956, https://doi.org/10.1002/jccs.202000179.

73. Syafiuddin, A.; Fulazzaky, M.A.; Salmiati, S.; Kueh, A.B.H.; Fulazzaky, M.; Salim, M.R. Silver nanoparticles adsorption by the synthetic and natural adsorbent materials: an exclusive review. Nano. Env. Engg. 2020, 5, 1-18, https://doi.org/10.1007/s41204-019-0065-3.

74. Hu, B.; Yin, N.; Yang, R.; Liang, S.; Liang, S.; Faiola, F. Silver nanoparticles (AgNPs) and AgNO3 perturb the specification of human hepatocyte-like cells and cardiomyocytes. Sci. Total Environ. 2020, 725, https://doi.org/10.1016/j.scitotenv.2020.138433.

75. Degenkolb, L.; Leuther, F.; Lüderwald, S.; Philippe, A.; Metreveli, G.; Amininejad, S.; Vogel, H.-J.; Kaupenjohann, M.; Klitzke, S. The fate of silver nanoparticles in riverbank filtration systems-The role of biological components and flow velocity. Sci. Total Environ. 2020, 699, https://doi.org/10.1016/j.scitotenv.2019.134387.

76. Dong, B.; Liu, G.; Zhou, J.; Wang, J.; Jin, R. Transformation of silver ions to silver nanoparticles mediated by humic acid under dark conditions at ambient temperature. J. Hazard. Mater. 2020, 383, https://doi.org/10.1016/j.jhazmat.2019.121190.

77. Esmaile, F.; Koohestani, H.; Abdollah-Pour, H. Characterization and antibacterial activity of silver nanoparticles green synthesized using Ziziphora clinopodioides extract. Environmental Nanotechnology, Monitoring \& Management 2020, 14, https://doi.org/10.1016/j.enmm.2020.100303.

78. Kalantari, K.; Mostafavi, E.; Afifi, A.M.; Izadiyan, Z.; Jahangirian, H.; Rafiee-Moghaddam, R.; Webster, T.J. Wound dressings functionalized with silver nanoparticles: promises and pitfalls. Nanoscale 2020, 12, 2268-2291, https://doi.org/10.1039/C9NR08234D.

79. Kraśniewska, K.; Galus, S.; Gniewosz, M. Biopolymers-based materials containing silver nanoparticles as active packaging for food applications-a review. Int. J. Mol. Sci. 2020, 21, https://doi.org/10.3390/ijms21030698.

80. Wang, X.; Li, T.; Su, X.; Li, J.; Li, W.; Gan, J.; Wu, T.; Kong, L.; Zhang, T.; Tang, M.; Xue, Y. Genotoxic effects of silver nanoparticles with/without coating in human liver HepG2 cells and in mice. Journal of Applied Toxicology 2019, 39, 908-918, https://doi.org/10.1002/JAT.3779.

81. Wang, W.; Yu, Z.; Alsammarraie, F.K.; Kong, F.; Lin, M.; Mustapha, A. Properties and antimicrobial activity of polyvinyl alcohol-modified bacterial nanocellulose packaging films incorporated with silver nanoparticles. Food Hydrocoll. 2020, 100, https://doi.org/10.1016/j.foodhyd.2019.105411.

82. Dang, F.; Huang, Y.; Wang, Y.; Zhou, D.; Xing, B. Transfer and toxicity of silver nanoparticles in the food chain. Environ. Sci. Nano. 2021, 8, 1519-1535, https://doi.org/10.1039/D0EN01190H.

83. Zhao, J.; Wang, X.; Hoang, S.A.; Bolan, N.S.; Kirkham, M.B.; Liu, J.; Xia, X.; Li, Y. Silver nanoparticles in aquatic sediments: Occurrence, chemical transformations, toxicity, and analytical methods. J. Hazard. Mater. 2021, 418, https://doi.org/10.1016/j.jhazmat.2021.126368.

84. Chang, X.; Wang, X.; Li, J.; Shang, M.; Niu, S.; Zhang, W.; Li, Y.; Sun, Z.; Gan, J.; Li, W.; Tang, M.; Xue, Y. Silver nanoparticles induced cytotoxicity in HT22 cells through autophagy and apoptosis via PI3K/AKT/mTOR signaling pathway. Ecotoxicol. Environ. Saf. 2021, 208, https://doi.org/10.1016/j.ecoenv.2020.111696.

85. Zhang, J.; Liu, S.; Han, J.; Wang, Z.; Zhang, S. On the developmental toxicity of silver nanoparticles. Mater. Des. 2021, 203, https://doi.org/10.1016/j.matdes.2021.109611.

86. Gao, X.; Li, R.; Sprando, R.L.; Yourick, J.J. Concentration-dependent toxicogenomic changes of silver nanoparticles in hepatocyte-like cells derived from human induced pluripotent stem cells. Cell Biol. Toxicol. 2021, 37, 245-259, https://doi.org/10.1007/s10565-020-09529-1.

87. Tortella, G.R.; Rubilar, O.; Durán, N.; Diez, M.C.; Martínez, M.; Parada, J.; Seabra, A.B. Silver nanoparticles: Toxicity in model organisms as an overview of its hazard for human health and the environment. J. Hazard. Mater. 2020, 390, https://doi.org/10.1016/j.jhazmat.2019.121974. 